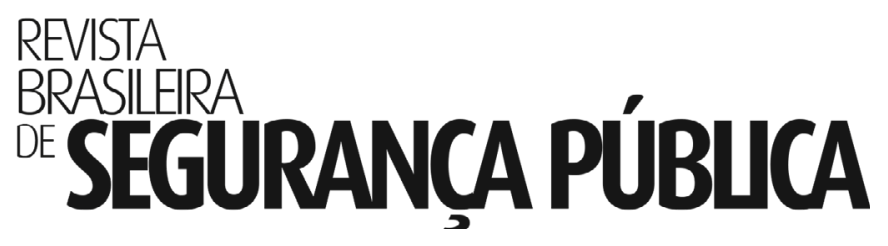

\author{
Volume 12 \\ Número 2 \\ Agosto/Setembro de 2018
}

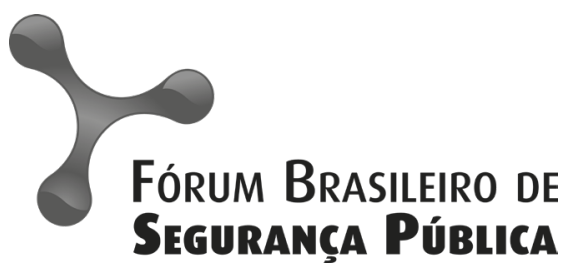

ISSN 1981-1659 


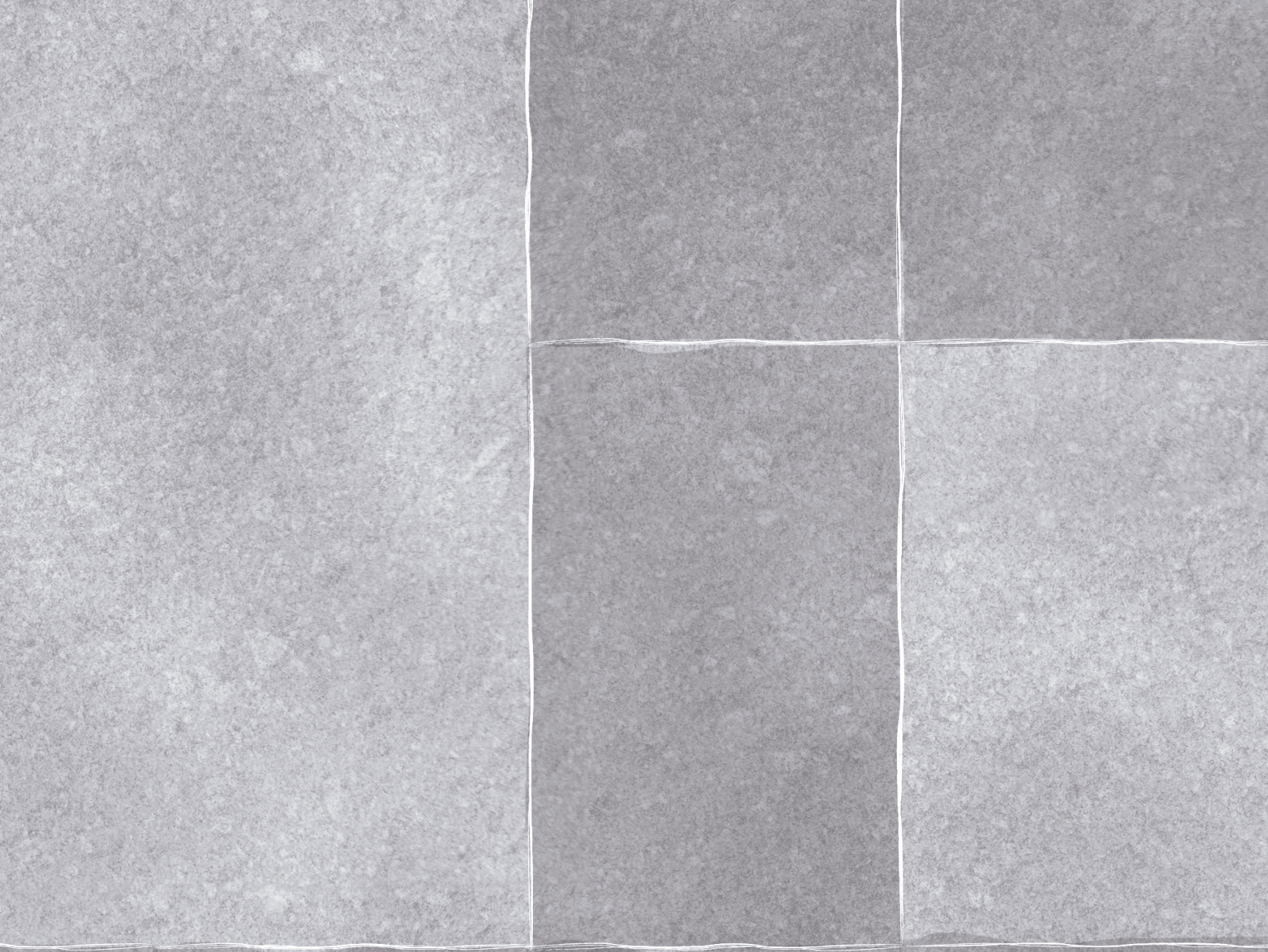




\title{
Governança Pública: um Estudo do Programa Dinheiro Direto em uma Unidade de Segurança em Goiás
}

\section{Carla Mendonça de Souza}

Mestre em Gestõo Organizacional pela Universidade Federal de Goiós, especialisto em Controladoria e Finanças, graduada em Administração. Atualmente é Administradora no Instituto Federal do Norte de Minas Gerais - Campus Arinos.

\section{César Augustus Adorno Ferreira Lima}

Mestre em Gestõo Organizocional pela Universidade Federal de Goiós, especialisto em Ciêncios Forenses, graduado em Formácio. Atualmente é professor de Pós-Graduação da Academia da Polícia Militar do Estado de Goiás e da Secretaria de Segurança Público/Universidade Estadual de Goiás. Trabalha na Polício Técnico-Científica do Estado de Goiás no cargo de Perito Criminal.

\section{Márcia Helena da Silva}

Mestre em Gestõo Organizacional pela Universidade Federal de Goiós, especialisto em Contabilidade e Controladoria, graduado em Ciências Contábeis. Atualmente é professoro efetiva da Universidade Federal de Goiás - Regional Catalõo.

\section{Manoel Rodrigues Chaves}

Doutor em Geografia pelo Instituto de Geociêncios e Ciências Exatos de Rio Claro, Mestre em Geografia pela Universidade Estadual Paulisto Júlio de Mesquito Filho, graduado em Geografio. Professor no Departomento de Geografia do Campus Catalõo do Universidode Federal de Goiós.

\section{André Vasconcelos da Silva}

Doutor em Ciências do Comportamento pela Universidade Federal de Brasília, Mestre em Psicologia, graduado em Psicologia. Atualmente é professor efetivo do Universidade Federal de Goiós - Regional Cotalõo.

\section{Serigne Ababacar Cisse Ba}

Doutor em Educação pela Universidade Federal de Uberlândio, Mestre em Administração pela Universidade Federal de Lavras, graduado em Administração pela Universidade Federal de Lavras. Atualmente é professor efetivo da Universidade Federal de Goiós - Regional Catalõo.

\begin{abstract}
Resumo
A participação de atores não estatais na implementação de programas e políticas públicas tem sido amplamente discutida pela áreo do Governança Pública. Em Goiás vem sendo implementado o Programa Dinheiro Direto nos Quartéis e nas Delegacios (PDDQD), que consiste em prestar assistêncio financeira em caráter suplementor diretomente às unidades locais de segurança pública. O PDDQD exige o participação da sociedade por meio da crioção de um Conselho comunitário de Segurança da Unidade/Unidade Executora Própria (CCSU/UEX). Com base nisso, o objetivo desse trabalho foi avaliar a implantação do PDDQD em uma unidade da Polício Técnico-Científica ò luz da teoria de governança pública. Trata-se de uma pesquiso qualitativa, aplicada, descritivo-exploratório, na qual foi realizado um estudo de coso. A coleta de dados foi realizada em diretrizes normativas e documentos criados na dinâmica regular do CCSU/UEx analisado. Ao avaliar as diretrizes, foi constatado que a institucionalização legal do PDDQD determina que os atributos do Governança Pública sejam desenvolvidos durante sua implementoção. O PDDQD favorece o fortalecimento de valores democróticos nas organizações policiais, pois a institucionalização desses atributos impõe esse desafio para os operadores de segurança pública das unidades que desejam implementar o CCSU/UEx. Em nível local, os documentos referentes oo CCSU/UEx indicaram uma prótica de Governança Pública. Contudo, em nível estadual, foram identificados problemas com relação à transparência na prestoção de contos.
\end{abstract}

Palavras - Chave Governança Pública; Segurança Pública; Coprodução do bem público; Controle Social. 
Dato de recebimento: 03/11/2017

Data de aprovação: 19/11/2018

DOI: 10.31060/rbsp.2018.v12.n2.871

\section{Abstract \\ Public Governance: A Study of the Program Dinheiro Direto in a Security Unit in Goiós}

Non-governmental actors' participation in public programs and politic implementing has been largely discussed for Public Governance area. In Goiás, the Programa Dinheiro Direto nos Quarteis e nas Delegacios (PDDQD) has been implemented, which consists of providing additional financial assistance directly to local public security units. The PDDQD requires the porticipation of society through the creation of a Community Safety Council of the Unit/Own Executing Unit (CCSU/UEx). Based on this, the objective of this work was to evaluate the implementation of the PDDQD in a unit of the Technical-scientific Police in the light of the public governance theory. It is a qualitative, applied, descriptive-exploratory research, in which o case study was carried out. The dato collection was made based on normative guidelines and documents created in the regular dynamics of the analyzed CCSU/UEx. In evaluating the guidelines, it was verified that the legal institutionalization of the PDDQD requires that the attributes of Public Governance be developed during its implementation. The PDDQD fovors the strengthening of democratic values in the police organizations, becouse the institutionalization of these attributes imposes this challenge for the public security operators of the units that wish to implement the CCSU/UEX. At the local level, the CCSU/UEx's documents indicated a Public Governance practice. However, at the state level, problems were identified with respect to transparency in accountability.

\section{Keywords}

Public Governance; Public safety; Coproduction of public services; Social Control. 


\section{INTRODUÇÃO}

A governança pública, de forma geral, busca compreender as diversas interaçóes existentes entre os atores que participam da elaboraçáo e implementação de programas e políticas públicas, sendo abordada tanto em pesquisas que analisam as relaçóes internas da estrutura estatal (ALVES; CALMON, 2008; BARBOSA; MEDEIROS, 2005; ESCOBAR, 2008; NUNES et al., 2012) como por pesquisas que analisam as relaçóes do Estado com atores não estatais, por exemplo, com organizaçóes privadas e/ou com movimentos sociais (DIAS 2012; KISSLER; HEIDEMANN, 2006; MATIAS-PEREIRA, 2010; MATTIA; BELLEN, 2014).

Geralmente, as pesquisas com foco nas relações internas entre órgãos estatais buscam identificar se a cooperaçáo interorganizacional aumenta a eficiência dos programas e políticas públicas, e se esta interação ocasiona redução na morosidade e nos custos gerados pela redundância burocrática (ALVES; CALMON, 2008; BARBOSA; MEDEIROS, 2005; ESCOBAR, 2008; NUNES et al., 2012). Já as pesquisas que analisam as relaçóes do Estado com atores externos à sua estrutura vão além desses aspectos e, comumente, questionam as concepçóes e ideologias que norteiam a inserção desses atores na elaboração e implementaçáo de programas e políticas públicas (DIAS, 2012; KISSLER; HEIDEMANN, 2006; MATIAS-PEREIRA, 2010; MATTIA; BELLEN, 2014).

A área da governança pública levanta muitos debates no campo da Administraçáo Pública, pois pode ser enxergada a partir de concepçóes distintas de racionalidade, como, por exemplo, o embate entre as vertentes econômica e sociológica. Enquanto a concepção econômica busca ressaltar a participação de atores não estatais na implementação de programas e políticas públicas por meio de mecanismos que permitem diminuir a estrutura do Estado, como as privatizaçóes e terceirizações, a concepção sociológica busca enfatizar a necessidade de maior participação popular, com vistas à maior legitimidade do sistema democrático (BEVIR; RHODES, 2001; BEVIR, 2010). Por causa desse embate, a governança pública é considerada ainda uma área em construçáo, que demanda pesquisas teórico-empíricas para sua consolidação (RAQUEL, 2012; DIAS, 2012; MATTIA; BELLEN, 2014).

Como foi apontado, o conceito de governança é carreado de discussóes e emba- 
tes teóricos devido ao seu uso abrangente em diversas áreas do conhecimento, inclusive sendo usado na rotina do mundo político e empresarial (ALCÂNTARA; PEREIRA; SILVA, 2015; SANTOS; PINHEIRO; QUEIROZ, 2014). Em que pese essa discussão, Alcântara, Pereira e Silva (2015) apontam que existe uma vertente mais democrática da governança pública e foi justamente essa perspectiva teórica utilizada neste trabalho. Conforme Denhardt (2012), Mattia e Bellen (2014) e Motta (2013), a governança pública evidencia a dinâmica das relaçóes políticas entre os atores na busca de melhorar a participação social e promover o fortalecimento da democracia.

Independentemente da perspectiva analítica sobre os arranjos sociais que se constroem, a governança pública, em sua essência, trata-se de "um modelo pautado na cooperaçáo entre Estado, mercado e sociedade civil em prol de objetivos comuns" (ALCÂNTARA; PEREIRA; SILVA, 2015, p. 12). Logo, a governança pública tem como finalidade a promoçáo da cidadania a partir da participação social em espaços de diálogo dentro dos quais é possível a definição de prioridades de agenda pública, bem como definição de metas coletivas e apoio popular que sustente politicamente as decisóes governamentais. Dessa forma, a coprodução de bem público pelos atores sociais envolvidos, uma coordenação pluricêntrica das açóes e políticas públicas, espaços deliberativos que fomentem uma democracia participativa, transparência e accountability se tornam características bem proeminentes dessa concepçáo democrática sobre governança pública, fomentando pluralismo, autonomia e participação (ALCÂNTARA;
PEREIRA; SILVA, 2015; BEVIR, 2010; DIAS, 2012; DINIZ, 2013; MATTIA; BELLEN, 2014; RAQUEL, 2012).

Náo obstante, a polícia é uma dimensão central da ação política de um governo (MONET, 2002), possuindo, em um estado democrático de direito, um papel importante na manutenção da democracia, pois "uma sociedade livre náo pode dispensar um certo nível de ordem, ou ainda, de previsibilidade, nas trocas sociais cotidianas" (MONET, 2002, p. 29). Ademais, a atuação da polícia, não somente em sua função ostensiva ou investigativa (uso legítimo da força), mas na forma de interagir com a sociedade, diz muito sobre a democracia de um país: "[...] a democracia depende muito da qualidade de sua polícia, assim como do apego dos policiais aos valores que a fundamentam" (MONET, 2002, p. 29). É necessário que a forma de agir e interagir da polícia com diversos atores sociais reforce na própria sociedade os princípios democráticos. Como afirma Monet (2002), "não só os cidadãos esperam da polícia que ela lhes assegure um certo nível de segurança, mas lhe pedem que o faça de tal modo que sua convicção democrática saia reforçada" (MONET, 2002, p. 29).

Neste sentido, o presente trabalho ousou estudar a governança pública no Programa Dinheiro Direto nos Quartéis e nas Delegacias (PDDQD), instituído pela Lei Estadual no 18.303 de 30 de dezembro de 2013 no estado de Goiás (GOIÁS, 2013). Esse programa surgiu para responder administrativa e financeiramente às necessidades prioritárias das unidades de Segurança Pública locais (Delegacias de Polícia Civil, Unidades da Polícia Militar, Corpo 
de Bombeiros Militar e Unidades da Polícia Técnico-Científica), flexibilizando o processo de compras públicas e a contrataçáo de serviços, ou seja, o programa visa amenizar os entraves burocráticos que dificultam mudanças necessárias à infraestrutura física e operacional dessas organizaçóes, bem como incentivar a autogestão local e, para isso, busca a participação da comunidade na deliberaçáo e controle desse projeto (GOIÁS, 2014a). Essa participação comunitária se dá por meio da criação de um Conselho Comunitário de Segurança da Unidade/Unidade Executora Própria (CCSU/UEx) (GOIÁS, 2013).

Dessa forma, a delimitação do tema desta pesquisa está relacionada ao estudo de governança pública no PDDQD implementado em uma unidade da Polícia Técnico-Científica situada na cidade de Cataláo, Sudeste do estado de Goiás. Diante do exposto, questiona-se: existe evidência da governança pública nas diretrizes normativas que orientam o PDD$\mathrm{QD}$ ? Como estas diretrizes vêm sendo implementadas? Para responder às questóes colocadas, o objetivo geral desse trabalho foi avaliar a implantação do PDDQD em uma unidade da Polícia Técnico-Científica à luz da teoria de governança pública, sendo que os objetivos específicos foram analisar se existe evidência de atributos da governança pública nos regulamentos que orientam o PDDQD e descrever como estes se apresentam nos documentos da referida unidade policial.

Este trabalho justifica-se pela possibilidade de apresentar contribuiçóes com o melhoramento da gestáo do PDDQD à luz da teoria de governança pública, bem como produzir conhecimento relacionado ao fortalecimento de uma cultura democrática participativa dentro das estruturas policiais. Ademais, esta pesquisa também pode trazer informaçóes que auxiliem atores envolvidos no controle social.

Para atender ao objetivo proposto, este trabalho contará com as próximas seções, em que serão apresentados a fundamentação teórica, método e resultados. A fundamentaçáo teórica será desenvolvida com base nos atributos que caracterizam a governança pública, os quais foram adaptados dos trabalhos de Raquel (2012), Dias (2012) e Mattia e Bellen (2014). Após o método, discorrer-se-á sobre as leis que institucionalizam o PDDQD e os resultados encontrados no caso analisado.

\section{Atributos da Governança Pública}

A Governança Pública é uma área ainda em construçáo no campo da Administração Pública (CALMON; COSTA, 2013; DIAS, 2012; GIGLIO; LUIZ, 2012; RAQUEL, 2012; SALM; MENEGASSO, 2012), e alguns estudos vêm buscando delimitar seus atributos e características, como é o caso de Dias (2012), Raquel (2012) e Mattia e Bellen (2014). A delimitação de atributos é necessária para que se possa, a partir deles, estabelecer categorias de análise do fenômeno em questáo.

Com base nos achados de Dias (2012), Raquel (2012) e Mattia e Bellen (2014) e na confrontaçáo com outras referências, foi possível, realizando algumas adaptaçôes, construir um rol objetivo de atributos da governança pública, os quais foram usados como unidades de análise nessa pesquisa e estáo apresentados no Quadro 1. Cabe ressaltar que houve uma delimi- 
tação dos atributos ao aspecto político da governança pública, dando seguimento à proposta de Mattia e Bellen (2014). De acordo com Denhardt (2012) e Motta (2013), a Administração Pública, enquanto campo de estudo, é muito ligada às operações práticas de governo e a mecanismos de gestão administrativa, necessitando de pesquisas que abordem também o sistema político. Melhor explicando, a governança pública ressalta a importância de estudar o papel político dos atores sociais e a dinâmica de suas relações político-sociais, complementando os estudos em relação à gestão e sua dimensão tecnocrática que é própria do campo do conhecimento da administração pública. E, por isso, dentro do espectro plural de conceito relacionado ao tema, Alcântara, Pereira e Silva (2015) a caracteriza como governança pública democrática.

\section{Quadro 1 - Atributos Políticos da Governanca Pública}

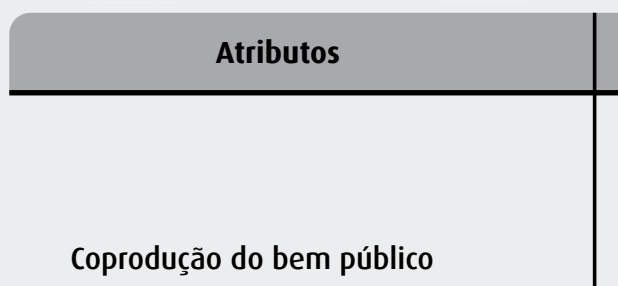

Bevir e Rhodes (2001); Sorensen e Torfing (2004); Santos (2005); Domingues, Xavier e Coelho (2006); Kissler e Heidemann (2006); Rosa e Frey (2007); Pieranti, Rodrigues e Peci (2007); Bovaird, 2007; Procopiuck e Frey $(2008 ; 2009)$; Martins e Lotta (2010); Ronconi (2011); Raquel (2012); Dias (2012); Mattia e Bellen (2014); Jakob (2014); Sorensen (2014); Frey, Penna e Czajkowski Jr. (2012).

Coordenação pluricêntrica, tendo
o Estado como ativador e mediador.

Peters e Pierre (1998); Kissler e Heidemann (2006); Procopiuck e Frey (2008); Pedersen, Sehested e Sorensen (2011); Dias (2012); Raquel (2012); Mattia e Bellen (2014); Sorensen (2014).

\begin{tabular}{l|l}
\hline $\begin{array}{l}\text { Democracia deliberativa fomentada } \\
\text { por meio de espaços e arenas que } \\
\text { promovam a participação. }\end{array}$ & $\begin{array}{l}\text { Sorensen e Torfing (2004); Procopiuck e Frey (2008); } \\
\text { Klering, Porsse e Guadagnin (2010); Ronconi (2011); } \\
\text { Pedersen, Sehested, Sorensen (2011); Raquel (2012); } \\
\text { Dias (2012); Jakob (2014); Mattia e Bellen (2014); } \\
\text { Sorensen (2014). }\end{array}$ \\
\hline $\begin{array}{l}\text { Institucionalização de arranjos } \\
\text { deliberativos participativos. }\end{array}$ & $\begin{array}{l}\text { Kissler e Heidemann (2006); Frey (2007); Kooiman et } \\
\text { al. (2008); Procopiuck e Frey (2008); Sorensen (2014). }\end{array}$ \\
\hline $\begin{array}{l}\text { Responsividade monitorada por } \\
\text { mecanismos que permitam a } \\
\text { transparência, a Accountability } \\
\text { e o Controle Social. }\end{array}$ & $\begin{array}{l}\text { Kissler e Heidmann (2006); Escobar (2008); Bevir } \\
\text { (2010); Dias (2012); Nunes et al. (2012); Mattia } \\
\text { e Bellen (2014). }\end{array}$ \\
\hline
\end{tabular}

Fonte: Adaptado de Raquel (2012), Dias (2012) e Mattio e Bellen (2014) e corroborado com as outras referêncios

A partir da relaçấo de atributos políticos da Governança Pública apontados, será apresentado neste referencial teórico uma breve explanaçáo sobre cada um deles. 


\section{Coprodução do bem público}

$\mathrm{Na}$ coprodução do bem público os processos de elaboração e implementação de programas e políticas públicas são realizados a partir de interaçóes entre atores públicos e privados (BOVAIRD, 2007; DIAS, 2012; MATTIA; BELLEN, 2014; PROCOPIUCK; FREY, 2008; RAQUEL, 2012; RONCONI, 2011; SORENSEN, 2014; SORENSEN; TORFING, 2004;). Segundo Bovaird (2007), a concepçáo de coproduçáo significa que os usuários e profissionais que compóem o uso e prestação de serviços públicos devem desenvolver relaçóes mútuas de cooperação para a produção do bem público, buscando superar os limites que os separam.

Assim, o conceito de coproduçáo do bem público tem grandes implicaçóes para as práticas democráticas de um governo representativo, pois insere usuários e comunidades locais no processo de tomada de decisão, ou seja, visualiza o papel dos cidadãos não só como usuários do serviço público, mas como gestores e responsáveis pela determinação e planejamento de programas e políticas públicas (BOVAIRD, 2007). Além disso, exige que os políticos e os profissionais diretamente ligados à Administração Pública busquem e desenvolvam novas formas de interface com os usuários do serviço e suas comunidades (BOVAIRD, 2007).

\section{Coordenação pluricêntrica, tendo o Esta- do como ativador e mediador}

A terminologia "coordenação pluricêntrica" vem sendo utilizada por Pedersen, Sehested e Sorensen (2011) e Sorensen (2014) para designar a emergência de um modelo de governança pública em que múltiplos centros de poder intera- gem de forma colaborativa e, ao mesmo tempo, competitiva em seus esforços para concretizarem resultados de governança. Segundo Sorensen (2014), pluricentrismo representa a interdependência nas relaçóes interorganizacionais a partir do compartilhamento de responsabilidades e poderes em busca de objetivos comuns, que só podem ser alcançados por meio de uma ampla coordenaçáo entre os atores envolvidos. Nessa perspectiva, as interaçóes não tomam a forma de um sistema unitário de governo soberano em que há uma relaçáo hierárquica, nem assumem a forma de um sistema onde cada ator tem plena autonomia e autoridade para decidir determinadas questóes (SORENSEN, 2014). A coordenação pluricêntrica desconhece o limite entre os aspectos horizontais e verticais de coordenação, enfatizando o aspecto interativo das relaçóes, em que um emaranhado de conflitos, consensos e jogos de poder permeiam e fortalecem essas interaçôes (PEDERSEN; SEHESTED; SORENSEN, 2011).

Nesse sentido, o conceito de coordenação pluricêntrica é aqui empregado levando em consideração as relaçóes entre atores estatais e não estatais. $\mathrm{O}$ antigo papel do Estado como dirigente ou gestor provedor solitário do bem público é substituído por um Estado que produz o bem público de forma conjunta com outros atores. Nesse novo papel, o Estado é visto como ativador e mediador das interaçóes sócio-políticas, ficando responsável pelo envolvimento dos atores, pelo compartilhamento de responsabilidades e pela promoçáo de espaços para discussão e deliberação de programas e políticas públicas (DIAS, 2012; KISSLER; HEIDEMANN, 2006; MATTIA; BELLEN, 2014; PETERS; 
PIERRE, 1998; PROCOPIUCK; FREY, 2008; RAQUEL, 2012).

\section{Democracia deliberativa fomentada por meio de espaços e arenas que promo- vam a participação}

Entre os atributos inerentes à Governança Pública se encontra a criaçáo de espaços destinados à discussáo e deliberaçáo de assuntos relacionados à coisa pública (DIAS, 2012; FREY, 2007; MATTIA; BELLEN, 2014; PROCOPIUCK; FREY, 2008; RAQUEL, 2012; RONCONI, 2011). Esses espaços possuem como finalidade fomentar a argumentação e dar voz à pluralidade de atores que querem participar da elaboração e/ou implementação de programas e políticas públicas, dessa forma, envolvem a discussão sobre a deliberação na presente democracia (AVRITZER, 2000; PAULA, 2005; RONCONI, 2011).

Para Avritzer (2000), o processo de deliberaçáo na presente democracia pode ser institucionalizado a partir de espaços que promovam a relação entre Estado e sociedade. Nesses espaços o aparelho do Estado desenvolveria mecanismos participativos juntamente com o tecido mobilizatório, garantindo a legitimidade das demandas populares (AVRITZER 2000; AVRITZER, 2008; PAULA, 2005; RONCONI, 2011). "Para isso é necessário criar arranjos institucionais que organizem a participação nas diferentes esferas governamentais" (PAULA, 2005, p. 9). Esses arranjos estimulariam a criaçáo dos espaços necessários ao diálogo livre e aberto entre Estado e cidadãos (KLERING; PORSSE; GUADAGNIN, 2010).

Estes arranjos geralmente são caracte- rizados por elementos como: a) cessáo de um espaço decisório por parte do Estado em favor de uma forma ampliada e pública de participação, permitindo a inclusão dos setores marginalizados na deliberaçáo a respeito do interesse público; b) socialização e/ou publicação da informação relevante, colocando em questáo a tradicional prerrogativa do executivo estatal de monopolizar o controle dos programas e políticas públicas; e c) abertura a múltiplas experiências, possibilitando que os diferentes interesses presentes na sociedade sejam explicitados e negociados num espaço público transparente (AVRITZER, 2000; KLERING; PORSSE; GUADAGNIN, 2010; PAULA, 2005).

\section{Institucionalização de arranjos delibera- tivos participativos}

Segundo Kooiman et al. (2008), o termo "instituição" denota os acordos, regras, direitos, procedimentos, leis, normas, papéis e crenças que fornecem um quadro geral sobre a estrutura da governança, orientando as deliberaçóes a serem formuladas, ou seja, são os princípios ou bases normativas que sustentam a estrutura ou formas de governança.

A governança pública, para ser eficaz, requer uma estrutura institucional relativamente ajustada que permita certa estabilidade e equilíbrio aos seus arranjos, visto que esses se formam a partir de relaçóes entre as diversas esferas públicas e privadas (KOOIMAN et al., 2008; PROCOPIUCK; FREY, 2008; RAQUEL, 2012). Nesse sentido, a governança pública passa a ser vista como o meio pelo qual um conjunto de atividades é dirigido, de forma que sejam obtidos resultados segundo algum padrão socialmente construído 
(HIRST, 2000 apud PROCOPIUCK; FREY, 2008).

Vale ressaltar que os aspectos informais também contribuem para a institucionalização de arranjos participativos (AVRITZER, 2008) e que as instituiçôes não necessariamente possuem um caráter determinístico (SORENSEN, 2014). A institucionalização da governança pública não é só explicada pelas bases normativas formais já estabelecidas, mas também pela capacidade de seus arranjos de se adaptarem às novas circunstâncias, de maneira que as interaçóes se atualizem (SORENSEN, 2014). Dessa forma, a estrutura de governança sofre ajustes contínuos e seus arranjos se tornam constantemente reintegrados e institucionalizados, pois sofrem modificaçóes como, por exemplo, seu tamanho a partir da entrada ou saída de algum ator, ou pela diferenciação por meio de novas ideias e informaçóes que os atores possam acrescentar (PROCOPIUCK; FREY, 2008).

Portanto, a governança pública não se constitui em um sistema de regras arraigadas por procedimentos legais e formais, nem é um sistema construído por regras exclusivamente informais, ao contrário disso, a governança pública busca um equilíbrio no desenvolvimento e institucionalização de mecanismos formais e informais que permita um mínimo de direção das açóes conduzidas coletivamente pelos atores que fazem parte dos arranjos participativos (PROCOPIUCK; FREY, 2008; ROSENAU, 2003; SORENSEN, 2014).

Responsividade monitorada por mecanismos que permitam a transparência, a

\section{accountability e o controle social}

A governança pública reconhece também a importância de mecanismos de controle e fiscalizaçáo que garantam a transparência e exponham o nível de responsividade na relaçáo entre Estado e sociedade (DIAS; CÁRIO, 2012; ESCOBAR, 2008; MATTIA; BELLEN, 2014; PIERANTI; RODRIGUES; PECI, 2007; RAQUEL, 2012). A responsividade significa até que ponto as deliberaçóes e açôes promovidas pelos administradores públicos correspondem e refletem os valores e interesses da sociedade, ou seja, até que ponto o sistema assegura que os ocupantes de cargos públicos se interessam pelos anseios sociais (DIAS; CÁRIO, 2012; Raquel, 2012; ROURKE, 1969, apud DENHARDT, 2012). Uma forma de identificar essa relaçáo entre as demandas da sociedade e a postura do Estado pode ser realizada a partir de mecanismos e princípios que permitam a transparência, a $a c$ countability e o controle social.

A transparência sempre foi um princípio presente na literatura sobre governança, seja ela desenvolvida por iniciativas privadas ou públicas (PIERANTI; RODRIGUES; PECI, 2007). A transparência no contexto da governança corporativa significa a disponibilizaçáo de qualquer tipo de informação às partes interessadas, não apenas aquelas impostas por leis ou regulamentos, mas qualquer informação de interesse do requerente. Dessa forma, a exposiçáo náo se limita apenas ao desempenho econômico-financeiro, mas também inclui outros dados, até os intangíveis (IBGC, 2009).

Nesse sentido, a burocracia estatal deve expor informaçôes relativas às suas 
açóes e deliberaçóes, de forma que se possa identificar se elas corroboram com o escrutínio público (BEVIR, 2010; DENHARDT, 2012; DIAS; CÁRIO, 2012; MATTIA; BELLEN, 2014; RAQUEL, 2012). Essa exposição de informações faz parte da literatura sobre governança pública, sendo fomentada tanto pelo princípio da transparência como pelo princípio da accountability (BEVIR, 2010; DIAS; CÁRIO, 2012; MATTIA; BELLEN, 2014; RAQUEL, 2012). A accountability é um princípio ético no qual se defende que a burocracia pública deve prestar contas de suas atividades e resultados à sociedade, bem como fomenta a responsabilizaçáo do burocrata público por valores como integridade, eficácia, eficiência e economicidade (NUNES et al., 2012; SCHEDLER; DIAMOND; PLATTNER, 1999; TCU, 2014). Dessa forma, envolve o confronto das informaçóes com a legalidade que rege o uso de recursos públicos (NUNES et al., 2012) e, em caso de eventual má-conduta, defende a aplicação de puniçóes (SCHEDLER; DIAMOND; PLATTNER, 1999). Com base nisso, entende-se que tanto o princípio da transparência como o da accountability compreendem a exposição de informaçóes pelo Estado à sociedade. Com base nisso, a sociedade pode acessar esses dados e monitorar as deliberaçóes e ações realizadas por órgãos estatais, bem como identificar se existe legitimidade na busca pelo bem público. Esse processo de monitorar as atividades estatais é chamado de Controle Social (BEVIR, 2010; PIERANTI; RODRIGUES; PECI, 2007).

\section{Método}

Trata-se de uma pesquisa qualitativa, de natureza aplicada, descritivo-exploratória, na qual foi realizado um estudo de caso em um Conselho Comunitário de Segurança da Unidade de Polícia Técnico-Científica (CCSU), Unidade Executora Própria (UEx) do 8 o Núcleo Regional de Polícia Técnica-Científica/Catalão ( $8^{\circ}$ NRPTC), localizada no sudeste de Goiás.

Este caso foi selecionado por conveniência, devido à facilidade de acesso pelos pesquisadores. Após a autorização dos membros da UEx, a qual foi registrada em ata da organização, os pesquisadores obtiveram acesso aos documentos analisados neste estudo, possibilitando descrever e entender o funcionamento do Programa Dinheiro Direto nos Quartéis e nas Delegacias (PDDQD) da UEx do $8^{\circ}$ NRPTC à luz dos atributos de Governança Pública os quais foram apresentados no Quadro 1 e explicados no referencial teórico: coprodução do bem público; coordenação pluricêntrica, tendo o Estado como ativador de mediador; democracia deliberativa fomentada por meio de espaços e arenas que promovam a participação; institucionalização de arranjos deliberativos participativos; responsividade monitorada por mecanismos que permitam a transparência, accountability e controle social.

A coleta de dados foi realizada em documentos criados na dinâmica regular de instalação e operacionalização do PDDQD, entre eles: a) atas de reunióes; b) termos ou contratos de convênio e/ou parceria; c) estatutos e regimentos internos; d) diretrizes normativas: Lei no 18.303 de 2013, que institui o PDDQD; Decreto ${ }^{\circ}$ 8.082 de 2014, que regulamenta os critérios de re $\neg$ passe e execução do PDDQD; e o Manual de Orientação para Constituição de Unidade Executora Própria de 2014. 
A coleta de dados foi realizada no período compreendido entre 23 de dezembro de 2015 a 05 de janeiro de 2016. Além disso, foi realizada consulta ao site da Secretaria de Segurança Pública para verificar a publicação das transferências de recursos.

Os dados coletados foram interpretados e analisados conforme seu conteúdo. De acordo com Bardin (1977), a análise de conteúdo pode ser realizada tanto de forma quantitativa como qualitativa. Nesta pesquisa foi realizada de forma qualitativa: "o que caracteriza a análise qualitativa é o facto de a inferência - sempre que é realizada - ser fundada na presença do índice (tema, palavra, personagem, etc.), e não sobre a frequência de sua aparição, em cada comunicação individual" (BARDIN, 1977, p. 115).

Entre as técnicas da análise de conteúdo se encontra a análise por categorias, que "funciona a partir de operaçôes de desmembramento do texto em unidades, em categorias segundo reagrupamentos analógicos" (BARDIN, 1977, p. 153). A categorização e a codificaçáo dos dados nos documentos foram realizadas com base nos atributos da governança pública $\mathrm{e}$ seus respectivos índices de análise, conforme exposto no Quadro 2.

Com base nos resultados obtidos e na análise realizada, foi possível produzir discussóes que pudessem subsidiar críticas que favorecessem uma melhor operacionalização do PDDQD. Os atributos da Governança Pública (democrática), que abrange o sistema político envolvido dentro da administração pública, favoreceram a construçáo de conhecimento que permitiu um posicionamento objetivo e parci- monioso sobre o PDDQD, propondo, de forma aplicada, melhorias sobre a operacionalizaçáo desse programa.

\section{Resultados e Discussão: Governança Pú- blica e o PDDQD}

O Programa Dinheiro Direto nos Quartéis e nas Delegacias (PDDQD), instituído pela Lei Estadual no 18.303 de 30 de dezembro de 2013, surgiu com a intenção de amenizar as dificuldades enfrentadas pela Secretaria da Segurança Pública de Goiás em promover o pronto atendimento das demandas de unidades de segurança locais, buscando amenizar a morosidade e a incapacidade de um processo licitatório centralizado (GOIÁS, 2014b). Entre as demandas que o programa visa atender se encontram: a conservação do prédio e equipamentos; a administração de repasses, subvençôes, convênios, doaçóes e arrecadações; a administração dos recursos provenientes do PDDQD; e a cooperação e a interaçáo com a sociedade para a promoçáo da segurança pública local. Com base nisso, o objetivo do PDDQD é "prestar assistência financeira em caráter suplementar, diretamente às Unidades que compóem os órgãos de segurança pública" (GOIÁS, 2014b, p. 5).

Para participar do programa as Unidades locais (Delegacias de Polícia Civil, Unidades da Polícia Militar, Corpo de Bombeiros Militar e Unidades da Polícia Técnico-Científica) devem criar um Conselho Comunitário de Segurança da Unidade (CCSU), também denominado Unidade Executora Própria (UEx) (GOIÁS, 2013). As UExs devem ser registradas como entidades de direito privado sem fins lucrativos e devem se constituir "por profissionais da segurança e membros da 


\begin{tabular}{|l|l|l} 
Categorias & Documentos & $\begin{array}{l}\text { Índices utilizados para } \\
\text { evidenciar a categoria }\end{array}$
\end{tabular}

Coprodução do bem público (A1)
-Atas de reuniões;

-Termos de convênio e parceria; -Estatutos e regimentos internos;

-Lei 18.303;

-Decreto $n^{\circ} 8.082$;

-Manual de Orientação para criação de UEx.
-Cooperação entre Estado, mercado e sociedade;

-Compartilhamento de responsabilidades e recursos;

-Interdependência.
-0 Estado fomenta a participação de outros atores nas deliberações;

-0 Estado não centraliza coordenação;

-Resistência ao controle único do Estado ou de outro ator.

- Manual de Orientação para criação de UEx.

-Atas de reuniões;

-Termos de convênio e parceria;

-Estatutos e regimentos internos;

-Lei 18.303;

-Decreto $n^{\circ} 8.082$;

- Manual de Orientação para

criação de UEx.

que promovam a

participação (A3)

Institucionalização
de arranjos
deliberativos
participativos (A4)

participativos (A4)
-Atas de reuniões;

-Termos de convênio e parceria;

-Estatutos e regimentos internos;

-Lei 18.303;

-Decreto $n^{\circ} 8.082$;

-Manual de Orientação para

criação de UEx.
- Criação de espaços que possibilitem a participação;

-Debate sobre os argumentos apresentados;

-Existência de desacordos e conflitos;

-Elementos de negociação, barganha e deliberação.

-Acordos e bases normativas que sustentam os arranjos;

-Atribuições e papeis de cada ator definidas;

-0s princípios e crenças que norteiam as deliberações e ações.

-Deliberações que refletem os valores e interesses da sociedade;

-Prestação de contas;

-Exposição de informações pelo Estado. 
comunidade local, que serão responsáveis pela formalização dos procedimentos necessários ao recebimento dos repasses do Programa, [...] bem como pela execuçáo e prestação de contas desses recursos" (GOIÁS, 2013).

As UExs devem possuir inscrição no Cadastro Nacional da Pessoa Jurídica (CNPJ) e devem se configurar como "órgãos deliberativos, executivos, consultivos e fiscalizadores, constituídos por um número ímpar de conselheiros, que deverá ser de, no mínimo, 05 (cinco) e, no máximo, de 15 (quinze) membros", sendo que a representaçáo da sociedade civil deve obedecer à proporcionalidade de 60\% (sessenta por cento) de membros e $40 \%$ (quarenta por cento) de pessoal da própria Unidade (GOIÁS, 2013). Com base nisso, pode-se afirmar que a lei que institui o PDDQD fomenta a coproduçáo do bem público, visto que compartilha responsabilidades com a sociedade civil, possibilitando a cooperação entre tais esferas.

O caso analisado possuía entre seus documentos o Estatuto do Conselho Comunitário de Segurança da Unidade (CCSU/ UEx), no qual se pode encontrar trechos que explicitam a coproduçáo do bem público, como por exemplo: "promoçáo da integração: poder público - comunidade"; "promover a aproximaçáo e a cooperaçáo entre a sociedade e a Unidade Local"; "incentivar a criaçáo do Conselho Comunitário de Segurança Municipais - CONSEG e trabalhar cooperativamente". Com base nisso, a composiçáo do conselho analisado possui cinco membros da comunidade e

Figura 1 - Organograma do ccsu

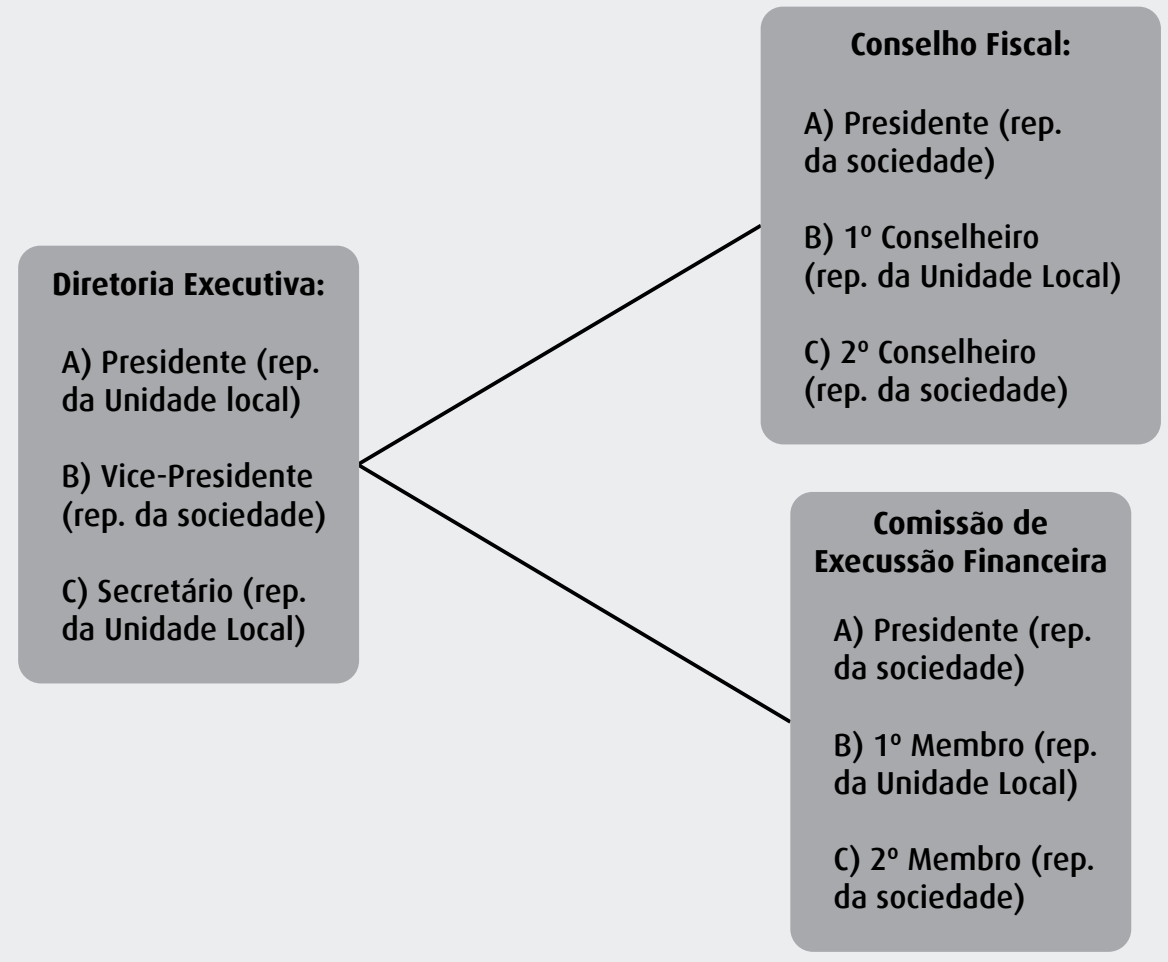


quatro membros da unidade local, conforme explicitado na Figura 1.

A coproduçáo do bem público pode ser evidenciada também a partir das parcerias que a UEx conseguiu realizar. Segundo atas das reunióes, a Unidade de Segurança conseguiu junto à prefeitura do município a doação de um local para instituir uma nova sede, sendo que a UEx foi também contemplada e instalada neste novo local. Além disso, conforme exposto em ata, a UEx conseguiu obter doação de móveis e computador de uma grande empresa situada na região, bem como firmou convênio junto ao SESI do município para que os servidores da unidade pudessem ter acesso à área de lazer. Com base nisso, pode-se afirmar que o PDDQD é uma política instituída pelo Governo do Estado de Goiás que propicia a coproduçáo do bem público, seja através de parcerias entre governos de esferas distintas, no caso, estadual e municipal, bem como através de parcerias com empresas da iniciativa privada.

É importante ressaltar também que na área da segurança pública já existiam outros conselhos comunitários, denominados CONSEGs. Os CCSU/UExs são conselhos distintos dos CONSEGs e possuem a função de atender especificamente aos requisitos do PDDQD. De acordo com o estatuto da entidade analisada, apesar de distintos, estes conselhos devem buscar trabalhar de forma integrada no sentido de promoverem açóes que resultem na melhoria da segurança local.

No que concerne ao atributo responsividade monitorada por mecanismos que permitam a transparência, a accountability e o controle social, pode-se afirmar que as instruçóes normativas que ins- titucionalizam o PDDQD contemplam a gestão compartilhada entre a comunidade e a Administração Pública, "possibilitando a participaçáa social e viabilizando o acompanhamento e a fiscalizaçáo popular dos recursos a serem aplicados em cada regiáo pela população local" (GOIÁS, 2014b, p. 5), pois, conforme Decreto No 8.082, de 30 de janeiro de 2014 - que regulamenta a Lei no 18.303/2013 e disciplina os critérios de repasse e execução do PDDQD -, a Secretaria de Segurança Pública de Goiás (SSP) deve divulgar, em sítio próprio, a transferência dos recursos financeiros destinados ao Programa e cabe às UExs, entre outras funções: a) "afixar, na sede da Unidade que representa, em local de fácil acesso e visibilidade, a relaçáo dos seus membros e demonstrativo sintético que evidencie os bens e materiais e os serviços que lhes foram fornecidos e prestados a expensas do Programa, com a indicaçáo dos valores correspondentes"; e b) "disponibilizar, quando solicitada, à comunidade local toda e qualquer informação referente à aplicaçáo dos recursos do Programa” (GOIÁS, 2014a).

No caso analisado, a organização disponibilizou toda a documentaçáo referente à criaçáo e desenvolvimento do programa para que esta pesquisa pudesse ser realizada, corroborando com as orientaçôes instituídas na legislação citada. Entretanto, apesar de existir acesso ao portal da transparência no website da Secretaria de Segurança do Estado de Goiás, não foi encontrada no mesmo a exposição das transferências de recursos específicas relacionadas à implementação e desenvolvimento do PDDQD. Dessa forma, pode-se afirmar que o Estado de Goiás não atendeu ao Art. 8 do Decreto No 8.082/2014, em 
que é determinado que "a SSP divulgará, em sítio próprio, a transferência dos recursos financeiros do Programa”, o que prejudica a ampla transparência, pois não são disponibilizadas as informaçôes conforme imposto pelo Decreto, embaraçando o processo de prestaçáo de contas (accountability), visto que atrasa e dificulta o monitoramento dos dados e a realização de confronto entre o montante de recursos transferidos e os resultados gerados, impactando negativamente na possiblidade de controle social.

Vale ressaltar que a UEx analisada não recebeu, até o momento dessa pesquisa, verba estadual para colocar em prática o plano de reformas criado, orçado e enviado à Secretaria de Segurança Pública (SSP). Essa realidade constatada na pesquisa impossibilitou identificar se a mesma exerce os princípios de transparência e accountability referentes aos recursos públicos recebidos e utilizados.

Por outro lado, tal fato levanta algumas questôes importantes relacionadas à distribuição de verba para as unidades de segurança pública no estado de Goiás: por que algumas organizaçôes e regiôes receberam verbas e outras não? A legislação aponta os critérios para recebimento de recursos, entretanto, o caso analisado, apesar de aparentemente atender aos requisitos, não recebeu verba.

A partir de pesquisa junto à SSP, Brandão (2015) conseguiu identificar as regiōes que foram beneficiadas pelo programa no ano de 2014, conforme exposto na Figura 2. Segundo consta nas referências de Brandáo (2015), esses dados foram levantados a partir de relatório forneci-do diretamen- te pela Gerência de Recursos Descentralizados. Ou seja, não foram levantados a partir de consulta ao website relacionado à transparência de recursos no Estado de Goiás. Ora, resta alguns questionamentos: se há regulamentação legal de critérios que definem a destinação da verba, como ela tem sido operacionalizada? Onde, de forma pública, é possível ter acesso a esses dados? Tais perguntas ficaram sem respostas e são necessários ajustes gerenciais para que seja respeitada a legislação, bem como os princípios de transparência e accountability.

No que se refere ao atributo de governança pública - coordenaçáo pluricêntrica, tendo o Estado como ativador e mediador - a fundação de uma UEx deve ocorrer perante a integração entre a Unidade de Segurança Pública e a comunidade. O gestor da Unidade local deve motivar e conscientizar a comunidade sobre a finalidade da constituiçáo da entidade e os benefícios que ela poderá proporcionar (GOIÁS, 2014b). Além disso, após sua fundação, deve realizar "gestōes permanentes no sentido de garantir que a comunidade local tenha participação sistemática e efetiva nas discussões das prioridades de segurança, desde a seleçáo destas necessidades até o acompanhamento do resultado do emprego dos recursos" (GOIÁS, 2014 b, p. 12). Com base nisso, pode-se afirmar que o manual de orientação criado pela própria Secretária de Segurança Pública de Goiás incentiva a existência de uma coordenaçáo pluricêntrica, tendo o Estado como ativador e mediador, pois cabe à Unidade local fomentar a participaçáo de outros atores nas deliberaçóes e açóes, bem como envolver harmonicamente esses atores, descentralizando sua 


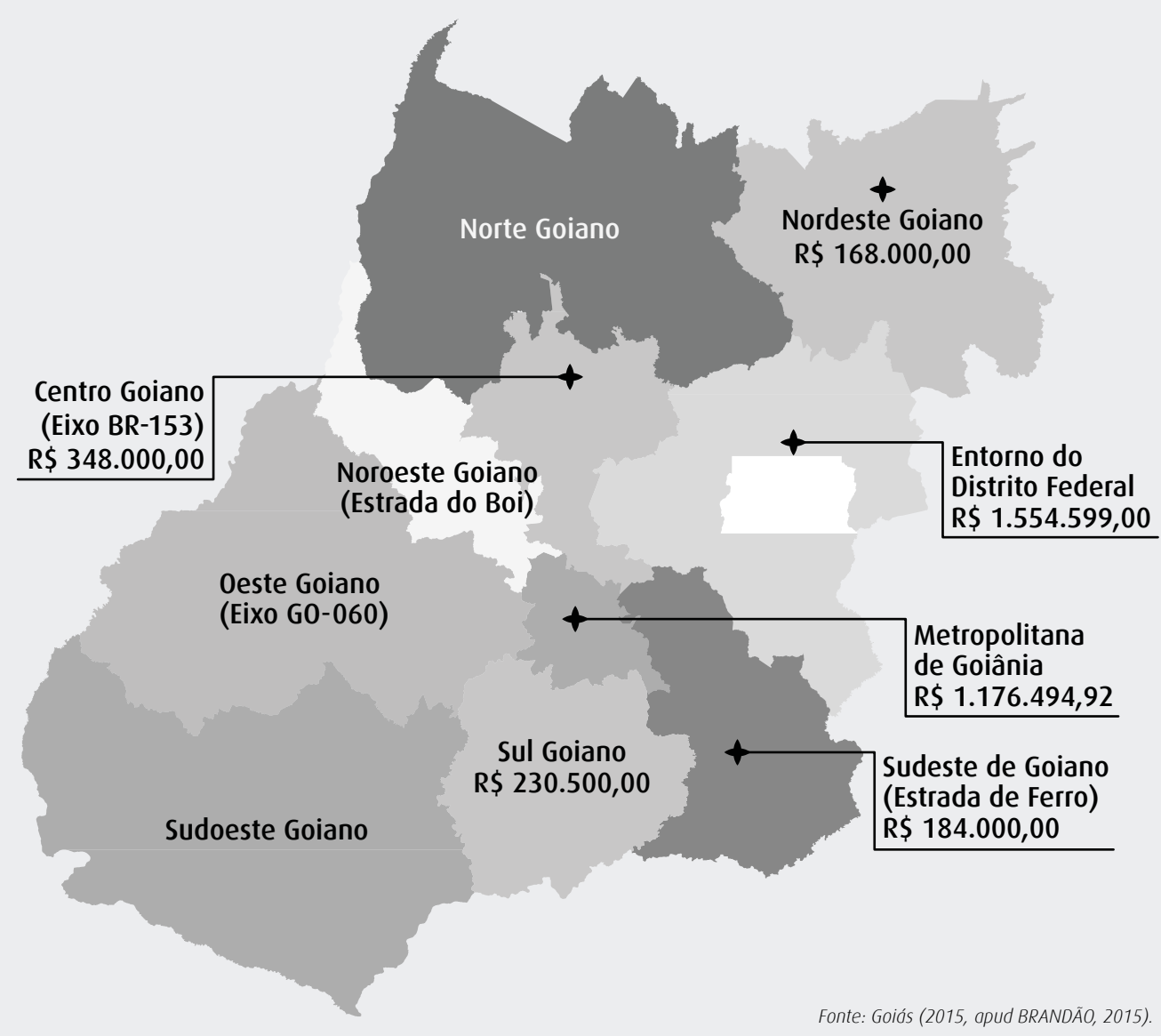

coordenação e a outorgando também aos atores representantes da sociedade civil. Conforme Estatuto da UEx analisada, todos os presentes na Assembleia Geral, entre eles, os servidores da Unidade local e os membros da comunidade, podem expor suas ideias e obter voz por meio dos seus representantes na entidade.

Outra instrução da Secretaria de Segurança Pública de Goiás é sobre a divulgação da implementação da UEx, que deve ser realizada a partir de meios de comunicação (rádio, jornal local, alto-falante), bem como a partir de encontros, palestras e reuniôes que demonstrem a importância e necessidade da fundação de uma Unidade Executora Própria (GOIÁS, 2014b). Portanto, o Manual de Orientação para Constituição de Unidade Executora Própria prevê que sejam criados espaços e arenas que promovam a participaçáo da sociedade na implementaçáo e desenvolvimento do PDDQD.

Entre os documentos analisados se encontrava o Edital de Convocação para Assembleia Geral, no qual a unidade local convocava "os membros da comunidade local para Assembleia Geral de Constituiçáo da Unidade Executora Própria (UEx)", em que foi realizada eleiçáo dos 
componentes da UEx e aprovado o Estatuto Social. Neste Edital constam ainda "Esclarecimentos sobre o PDDQD" e uma breve explanação do que vem a ser uma UEx, ressalvando-se que a mesma deve ser "integrada por servidores da mesma unidade [...] e membros da comunidade local". Anexados a este edital se encontravam três comprovantes de contrato referentes a publicidades e propagandas do edital de convocaçáo em duas rádios e um jornal localizado no município onde se encontra a unidade local.

Após a reuniáo (assembleia geral) para aprovação do Estatuto, realizada em março de 2014, foram realizadas mais três reunióes entre 2014 e 2015. Todas foram realizadas após divulgação do edital de convocaçáo. De acordo com a ata da primeira reuniáo, a pauta de discussão girou em torno do "primeiro plano de aplicação financeira e reforma da edificaçáo da nova sede, o qual foi doado pela prefeitura do município". Pela vista nas assinaturas todos os envolvidos diretamente na composição da UEx se encontravam presentes nesta reuniáo, ou seja, estavam presentes quatro membros da unidade local e cinco membros da comunidade.

Segundo consta na ata da segunda reuniáo a discussáo girou em torno de dois pontos principais: mudança de endereço e solicitação de doação de materiais a uma empresa situada no município, entre estes materiais se encontravam: um ar condicionado, um refrigerador, um purificador de motor, uma mesa, um armário misto, cinco cadeiras e um roupeiro. Conforme ata, houve unanimidade no colegiado sobre as açóes que seriam realizadas. Vale ressaltar que estavam presentes seis membros na reunião, dos quais quatro eram representantes da sociedade e dois eram representantes da unidade local. $\mathrm{Na}$ ata da terceira reunião a pauta de discussáo girou em torno do recebimento e da publicaçáo das doaçôes solicitadas, além disso, foi falado sobre as novas eleiçóes e troca dos membros do conselho no próximo ano.

Com base na análise desses documentos, pode-se afirmar que existiram espaços e arenas onde a sociedade esteve presente, através dos seus representantes, no conselho da UEX, e que houve publicação deste edital convocando outros membros da sociedade para assistirem tal evento, entretanto, nas atas náo consta a participaçáo de outros indivíduos civis, que não os que compóem o CCSU/UEx. O que levanta as seguintes perguntas: Será que realmente os editais de convocação de reunião tem tido ampla divulgaçáo, ou trata-se apenas de um registro documental desprovido de alcance social? Se tem amplo alcance, até que ponto a sociedade civil se interessa em participar ativamente na elaboração e implementaçáo de programas e políticas públicas?

Essas perguntas são pertinentes e devem ser mais exploradas em pesquisas futuras, pois, embora a participaçáo da sociedade seja imprescindível para o fortalecimento da democracia, observa-se, atualmente, que há uma forte desconfiança em relaçáo aos espaços participativos e de sua real efetividade (SÍGOLO; MASCARENHAS, 2012). Isso se deve, em partes, porque "os espaços participativos se relacionam com o sistema político representativo, até mesmo, reproduzindo muitas de suas distorçôes" (SÍGOLO; MASCARENHAS, 2012, p. 114). 
Quanto ao atributo institucionalizaçáo do arranjo, tanto a Lei 18.303/2013 como o Decreto No 8.082/2014 abordam claramente que a UEx deve se constituir a partir de um Conselho Comunitário em que os papéis e responsabilidades de cada ator devem ser expostos através de Estatuto. A organização analisada possuía tal documento, criado e lavrado em assembleia geral, conforme ata assinada pelos atores que compóem o arranjo. No estatuto consta a descrição de como deve se estruturar o organograma desta organização, bem como os papéis que cada ator deve desempenhar. Além disso, os valores e crenças institucionais do arranjo, como a cooperação, podem ser observados a partir de afirmaçóes como: "promoção da integração: poder público - comunidade"; "promover a aproximaçáo e a cooperação entre a sociedade e a Unidade Local"; "incentivar a criação do Conselho Comunitário de Segurança Municipais - CONSEG e trabalhar cooperativamente".

A partir de uma análise mais ampla sobre o assunto, e se baseando no que foi exposto, é importante ressaltar que o PDD$\mathrm{QD}$, em sua constituição normativa, traz consigo os atributos de governança. Tais características tornam-se um grande desafio para os operadores de segurança pública (policiais civis, militares, técnico-científicos e bombeiros militar) das unidades que desejam implementar o CCSU/UEx para obtenção de verbas, pois impóem características de participação social em estruturas organizacionais historicamente fechadas e pouco afeitas à accountability.

A transparência, a prestação de contas, o controle social e accountability podem ser interpretados dentro das organizaçóes policiais como uma punição ou algo que restrinja a autonomia policial. Entretanto, são princípios que fortalecem o exercício da atividade policial, trazendo mais legitimidade em suas açóes, bem como proporciona modernização ao que se refere aos anseios da sociedade, e contribui significativamente para a melhoria da qualidade dos serviços prestados (CORDEIRO, 2016; LIMA, 2008; MUNIZ; PROENÇA JUNIOR, 2007). Não obstante, o controle social, accountability, a transparência e a prestação de contas da polícia são mecanismos virtuosos de uma cultura democrática madura (LIMA, 2008). Nesse sentido, o estudo realizado demonstra que falta avançar nesse aspecto da governança pública, pois, em decorrência da falta de publicizaçáo de informaçóes, a transparência e a prestação de contas sobre a transferência de recursos da Secretaria de Segurança Pública do Estado de Goiás para as UEx contempladas ficaram prejudicadas.

Por oportuno, é importante ressaltar que cultivar e fortalecer uma cultura democrática dentro das instituiçóes policiais se torna imperativo diante de um novo modelo de cidadania que vem se apresentando dentro da sociedade brasileira. Náo se espera que o Estado coloque ênfase apenas na eficiência administrativa e na centralização dos processos decisórios. A gestáo pública possui o desafio de criar mecanismos democráticos que favoreçam a participação social, construindo espaços onde possam ocorrer de forma institucionalizada o diálogo e o debate, com a finalidade de negociar e deliberar sobre as prioridades das agendas públicas (LIMA, 2008; RONCONI, 2011). 
Obviamente, esses princípios de transparência, accountability e participação social não se referem a conteúdos sigilosos relacionados à investigaçáo ou aos dados de inteligência da atividade policial, ou até mesmo às informaçóes organizacionais que possam colocar em cheque a segurança institucional. O que é pauta dessa discussão é a qualidade da relação da polícia como essa sociedade que tem amadurecido no exercício de sua cidadania, exigindo posturas mais transparentes, e que defende que a promoção da ordem pública esteja sob a égide da lei e da geração de valor social na prestação do serviço público.

Com o PDDQD ou com qualquer outra política pública que possui os atributos de governança pública, a polícia é desafiada a se tornar uma estrutura ativadora que aciona e coordena outros atores a produzirem bem público com ela, tornando-se uma estrutura burocrática que em conjunto com outros atores é capaz de produzir bem público e gerar valor social (RONCONI, 2011). Dessa forma, os cidadãos se tornam mais participativos, coprodutores e parceiros na promoçáo de segurança pública. O PDDQD demonstra que, se houver interesse político, a partir de uma gestáo de mudança de cultura organizacional, é possível, dentro da polícia, "consolidar e reinventar os instrumentos e espaços participativos no cotidiano das interaçóes possíveis da sociedade com o poder público, assim como concretizar a participação popular como um princípio [...]" (SÍGOLO; MASCARENHAS, 2012, p. 115).

Extrapolando para o âmbito do policiamento, não é isso que os fundamentos do policiamento comunitário também propóem? Por que não efetivar essas estratégias para além da área operacional, mas em toda sua estrutura administrativa? Ora, ao discorrer sobre o policiamento moderno, entre eles o policiamento comunitário, Moore (2003) defende que esses conceitos devem ser entendidos náo como programas de gestáo, mas, sobretudo, como estratégias organizacionais que afetam significativamente a cultura institucional. Dessa forma, os atributos de governança podem ser boas diretrizes para fortalecer os princípios democráticos dentro das estruturas policiais.

Além disso, a governança pública não descarta a possibilidade de conflito entre os atores sociais, haja vista que, com a institucionalização de espaços deliberativos, fomenta controle social e participaçáo de diferentes atores nos processos de decisão, e isso pode gerar conflitos e disputas de interesses políticos (RONCONI, 2011). Nesse sentido, não foi possível perceber na análise dos documentos da UEx da unidade de Polícia Técnico-Científica se houve conflitos para deliberação de qualquer tema. Tal discussáo foi uma limitação da metodologia adotada nessa pesquisa e abre uma porta para o avanço de estudos relacionados ao protagonismo ou não dos integrantes da sociedade civil dentro do PDDQD e se há conflitos de interesse com os membros que são operadores de segurança pública.

Sem sombras de dúvida, os atributos de governança pública do PDDQD, dentro da perspectiva teórica adotada, promovem e fortalecem uma cultura democrática participativa. Esse modelo de gestão fomenta a construçáo de uma democracia 
que extrapola o aspecto representativo, pois com a presença ativa dos atores nos debates e processos decisórios, promove uma democracia participativa (RONCONI, 2011). Esse modelo de gestão é um avanço dentro das estruturas policiais, pois, dentro do âmbito da gestão financeira descentralizada que o PDDQD promove, os operadores de segurança pública sáo estimulados a trazer a sociedade civil, mesmo que minimamente, para dentro da organizaçáo com a finalidade de discutir e auxiliar na resolução de temas que são importantes para as unidades locais de segurança pública.

\section{Considerações Finais}

Este estudo teve como objetivo analisar se existe evidência de atributos da governança pública nos regulamentos que orientam o PDDQD e descrever como estes se apresentam nos documentos de uma Unidade Executora. Os atributos da governança pública usados como unidades de análise foram: coprodução do bem público (A1); coordenação pluricêntrica, tendo o Estado como ativador e mediador (A2); democracia deliberativa fomentada por meio de espaços e arenas que promovam a participação (A3); institucionalização de arranjos deliberativos participativos (A4); responsividade monitorada por mecanismos que permitam a transparência, a accountability e o controle social (A5).

Ao analisar as diretrizes normativas do PDDQD foi constatado que a institucionalização legal desse programa determina que os atributos da Governança Pública sejam desenvolvidos em sua implementação. Os documentos referentes à CCSU/ UEx analisada também permitiram identificar resultados positivos sobre a imple- mentaçáo desses atributos, visto que foi possível encontrar conteúdo que retrata as categorias encontradas na literatura.

É importante evidenciar que o PDDQD é um grande avanço no que se refere aos atributos de governança pública, pois favorece o fortalecimento de valores democráticos em organizaçóes pouco afeitas à transparência, prestaçáo de contas e accountability. A institucionalização desses atributos para a operacionalizaçáo do PDDQD, inclusive a participação da sociedade civil em espaços deliberativos, é um importante desafio para os operadores de segurança pública das unidades que desejam implementar o CCSU/UEx para obtenção de verbas.

Entretanto, é importante ressaltar que o caso analisado possui uma limitaçáo quanto ao atributo referente à transparência, accountability e controle social (A5), uma vez que a organização analisada não recebeu recurso financeiro direto do Estado de Goiás, mas recebeu apenas doações de móveis por uma empresa privada e um prédio pela prefeitura do município, o que impede um monitoramento maior sobre o recebimento e a aplicação de dinheiro público. Além disso, foi constatado que o Estado de Goiás não publica de forma específica os recursos destinados ao PDDQD, o que prejudica a ampla transparência, pois não disponibiliza as informaçóes em seu website, conforme imposto pelo Decreto No 8.082/2014, embaraçando os processos de prestação de contas e controle social. Dessa forma, sugere-se que seja melhorada a prestaçáo de contas em relação à destinação de verba e a transparência quanto a escolha das CCSU/UEx's selecionadas. 
Outro aspecto que chamou a atenção foi que nas atas não consta a participação de outros indivíduos civis diferentes daqueles que já eram integrantes da CCSU/ UEx. A baixa participação social nos espaços e arenas (A3) dificulta o fortalecimento de uma cultura democrática participativa. Nesse sentido, é necessário avançar não apenas dentro das organizaçóes estatais, mas também como sociedade, criando um ambiente de confiança e de efetividade das ações nesses espaços deliberativos.

Outras limitaçóes podem ser apontadas neste estudo, como o fato de ter sido elaborado apenas em cima de dados oriun- dos de documentos, que poderiam ser confrontados com entrevistas aos atores envolvidos. Além disso, a amostra de apenas uma UEx e o curto espaço de tempo para coleta de pesquisa impóe limites a generalizaçóes sobre a análise do PDDQD. Conforme Goiás (2015, apud, BRANDÁO, 2015), no ano de 2014, 149 unidades executoras foram cadastradas no Progra $\neg \mathrm{ma}$, das quais 28 receberam recursos. Dessa forma, outras pesquisas poderiam ser desenvolvidas, abarcando um número maior de amostra e adotando outras metodologias, haja vista a importância de se compreender o desenvolvimento de programas e políticas públicas que possuem participação social.

\section{Referências Bibliográficas}

ALCÂNTARA, Valderí de Castro; PEREIRA, José Roberto; SILVA, Érica Aline Ferreira. Gestão Social e Governança Pública: aproximações e (de)limitações teórico-conceituais. Revista de ciências da Administração, v. 17, Edição Especial, 2015, p. 11-29.

ALVES, Maria Fernanda Colaço; CALMON, Paulo Carlos Du Pin. Múltiplas chibatas? - governança da política de controle da gestão pública federal. In: Encontro de Administração Pública e Governança, 3, 2008, Salvador. Anais... Salvador: Associação Nacional de Pós-Graduação e Pesquisa em Administração, 2008.

AVRITEER, Leonardo. Teoria democrática e deliberação pública. Lua Nova, n.49, 2000, p. 25-46.

AVRITEER, Leonardo. Instituições participativas e desenho institucional: algumas considerações sobre a variação da participação no Brasil democrático. Opinião Pública, Campinas, v.14, n.1, 2008, p.43-64.

BARBOSA, Sheila Cristina Tolentino; MEDEIROS, Janann Joslin. Configuração de arranjos interorganizacionais e

implementação de políticas públicas. Cadernos EBAPE, v.3, n.2, 2005, p.1-16.

BARDIN, Laurence. Análise de Conteúdo. Lisboa: Edições 70, 1977.

BEVIR, Mark. Democratic Governance: A Genealogy. In: Conference on Interpreting Democratic Governance, 2010, De Montfort University, UK. Anais... UK, 2010. Disponível em: <http://wpsa.research.pdx.edu/ meet/2012/bevirpaper.pdf >. Acesso em: 21 ago. 2017.

BEVIR, Mark.; RHODES, Rod. A. W. A Decentered Theory of Governance: Rational Choice, Institutionalism, and Interpretation. Institute of Governmental Studies, University of California, Berkeley, 2001.

BOVAIRD, Tony. Beyond engagement and participation: user and community coproduction of public services. Public Administration Review, v.67, n.5, 2007, p. 846860. DOI:10.1111/j.1540-6210.2007.00773.x 
BRANDÃO, Pollyana. Os impasses e os benefícios do Programa Dinheiro Direto nos Quartéis e Delegacias-PDDQD nas unidades policiais militares do Estado de Goiás. REBESP, Goiânia, v.8, n.1, 2015, p. 42-50.

CALMON, Paulo; COSTA, Arthur Trindade Maranhão. Redes e governança das políticas públicas. Revista de Pesquisa em Políticas Públicas, n. 01, jul. 2013.

CORDEIRO, Ivana Oliveira. Accountability e qualidade da atividade policial na Segurança Pública. 2014. $94 f$. Dissertação ( Mestrado Profissional em Segurança Pública, Justiça e Cidadania) - Universidade Federal da Bahia, Faculdade de Direito, Salvador-BA, 2014.

DENHARDT, Robert. Teorias da Administração Pública. Tradução da 6 a edição norte-americana por Francisco G. Heidmann. São Paulo: Cengage Learning, 2012.

DIAS, Taisa. Governança Pública: uma concepção teórico-analíitca aplicada no governo do estado de Santa Catarina a partir da implantação das Secretarias de Desenvolvimento Regional. 2012. 356 f. Tese (Doutorado em Administração) - Universidade Federal de Santa Catarina, Centro Sócio-Econômico, Florianópolis-SC, 2012.

DIAS, Taisa; CÁRIO, Silvio Antonio Ferraz. Governança pública: um ensaio da gênese do movimento que coloca o Estado voltado para a perspectiva econômica de desenvolvimento. In: Encontro de Administração Pública e Governança, 5, 2012, Salvador. Anais... Salvador: Associação Nacional de Pós-Graduação e Pesquisa em Administração, nov. 2012.

DINIZ, Eli. Desenvolvimento e Estado desenvolvimentista: tensões e desafios da construção de um novo modelo para o Brasil do século XXI. Revista de Sociologia e Política, v. 21, n. 47, 2013, p. 9-20.

ESCOBAR, Cecília Maria de Souza. Governança estratégica em redes de políticas públicas: a experiência do Programa Bolsa Família. In: Encontro de Administração Pública e Governança, 3, 2008, Salvador. Anais... Salvador: Associação Nacional de Pós-Graduação e Pesquisa em Administração, nov. 2008.
FREY, Klaus. Governança urbana e participação pública. Revista de Administração Contemporânea - Eletrônica, v.1, n.1, 2007, p.136-150.

GIGLIO, Ernesto Michelangelo; LUIZ, Alfredo José Barreto; NAJBERG, Estela. Analysis of public policies implementation for environmental management in Brazil: the contribution of social network theory. Agroalimentaria, Mérida, v.18, n.35, 2012, p.87-101.

GOIÁS. Lei ñ 18.303, de 30 de dezembro de 2013. Institui o Programa Dinheiro Dire-to nos Quartéis e nas Delegacias - PDDQD -, no âmbito da Secretaria da Segurança Pública, e dá outras providências. Diário Oficial, Goiânia, G0, 31 dez. 2013. Disponível em: <http://www.ssp.go. gov.br/wp-content/uploads/2014/03/lei-no-18-303. pdf>. Acesso em: 10 dez. 2015.

GOIÁS. Decreto n 8.082, de 30 de janeiro de 2014. Regulamenta a Lei $n^{0} 18.303$, de 30 de de-zembro de 2013, para disciplinar os critérios de re-passe e execução do Programa Dinheiro Direto nos Quartéis e nas Delegacias (PDDQD). Diário Oficial, Goiânia, GO, 05 fev. 2014a. Disponivel em: <http://www.ssp.go.gov.br/ wp-content/uploads/2014/03/decreto-8-082-pddqd. pdf>. Acesso em: 10 dez. 2015.

GOIÁS. Manual de Orientação para Consti-tuição de Unidade Executora Própria (UEx). Goiânia: Secretaria de Segurança Pú-blica, 2014b. Disponível em: <http:// www.ssp.go.gov.br/wp-content/uploads/2014/03/ manual--de-orientacao-para-constituicao-de-unidade-executora-propria.pdf>. Acesso em: 10 dez. 2015.

INSTITUTO BRASILEIRO DE GOVERNANÇA CORPORATIVA (IBGC). Código das melhores práticas de governança corporativa. 4.ed. São Paulo: IBGC, 2009.

KISSLER, LeO; HEIDEMANN, Francisco. Governança pública: novo modelo regulatório entre Estado, mercado e sociedade? Revista de Administração Pública, v.40, ก.3, 2006, p.479-499.

KLERING, Luis Roque; PORSSE, Melody; GUADAGNIN, Luis Alberto. Novos caminhos da Administração Pública brasileira. Análise, Porto Alegre, v.21, n.1, 2010, p.4-17. 
KOOIMAN, Jan; BAVINCK, Maarten; CHUENPAGDEE, Ratana; MAHON, Robin; PULLIN, Roger. Interactive governance and governability: an introduction. The Journal of Transdisciplinary Environmental Studies, v.7, n.1, 2008, p.1-11.

LIMA, João Marcelo Maciel. Democracia e Accountability: Mecanismos de controle externo na Polícia Militar do Estado de São Paulo (1989-2007). Aurora, ano 2, n. 3, dez. 2008

MATIAS-PEREIRA, José. A governança corporativa aplicada no setor público brasileiro. Administração Pública e Gestão Social, Viçosa, v.2, n.1, 2010, p.109-134.

MATTIA, Clenia; BELLEN, Hans Michael Van. A experiência da governança pública na elaboração dos Planos Estaduais de Cultura. In: Encontro da Associação Nacional de Pós-graduação e Pesquisa em Administração, 38, 2014, Rio de Janeiro. Anais... Rio de Janeiro: Associação Nacional de Pós-Graduação e Pesquisa em Administração, set. 2014.

MONET, Jean Claude. Polícias e Sociedades na Europa. 1.ed. São Paulo: EDUSP, 2002.

MOORE, Mark Harrison. Policiamento Comunitário e Policiamento para Solução de Problemas. In: TONRY, M.; MORRIS, N. (Org.). Policiamento Moderno. São Paulo: Editora da Universidade de São Paulo, 2003, p. 115-175.

MOTTA, Paulo Roberto de Mendonça. 0 estado da arte da gestão pública. Revista de Administração de Empresas, v.53, n.1, 2013, p. 82-90.

MUNIZ, Jacqueline; PROENÇA JUNIOR, Domício. De La Accountabillity Selectiva a La Plena Responsabilidad Policial. In: Haydee Caruso; Jacqueline Muniz; Antonio Carlos Carballo Blanco. (Org.). Polícia, Estado y Sociedad: Prácticas y Saberes Latinoamericanos. 1 ed. Rio de Janeiro: Publit Seleções Editoriais, v. 1, 2007, p. 21-74.

NUNES, Paulo Roberto de Carvalho; LIMA, Alexandre Oliveira; NOGUEIRA, Fábio Luiz Benício Maia; Oliveira, Marcelle Colares. Evidências de práticas de governança na administração pública do estado do Ceará. In: Encontro de Administração Pública e Governança, 5, 2012, Salvador. Anais... Salvador: Associação Nacional de Pós-Graduação e Pesquisa em Administração, nov. 2012.

PAULA, Ana Paula Paes de. Administração Pública brasileira entre o gerencialismo e a gestão social. Revista de Administração de Empresas, v. 45, n.1, 2005.

PEDERSEN, Anne; SEHESTED, Karina; SORENSEN, Eva. Emerging Theoretical Understanding of Pluricentric Coordination in Public Governance. The American Review of Public Administration, v.41, n.4, 2011, p.375-394.

PETERS, B. GUy; PIERRE, John. Governance without government? rethinking Public Administration. Journal of Public Administration Research and Theory, v.8, n.2, 1998, p.223-243.

PIERANTI, Octavio; RODRIGUES, Silvia; PECl, Alketa. Governança e New Public Management: convergências e contradições no contexto brasileiro. In: Encontro da Associação Nacional de Pós-graduação e Pesquisa em Administração, 31, 2007, Rio de Janeiro. Anais... Rio de Janeiro: Associação Nacional de Pós-Graduação e Pesquisa em Administração, set. 2007.

PROCOPIUCK, Mario; FREY, Klaus. Governança e redes em políticas de caráter público. In: Encontro de Administração Pública e Governança, 3, 2008, Salvador. Anais... Salvador: Associação Nacional de Pós-Graduação e Pesquisa em Administração, nov. 2008.

RAQUEL, Izabela. Governança pública: a consolidação de uma matriz com atributos que caracterizam o tema, na perspectiva de especialistas. 2012. 173 f. Dissertação (Mestrado em Administração) - Universidade Federal de Santa Catarina, Centro Sócio-Econômico, Programa de Pós-Graduação em Administração, Florianópolis, 2012.

RONCONI, Luciana. Governança pública: um desafio à democracia. Emancipação, Ponta Grossa, v.11, n.1, 2011, p.21-34.

ROSENAU, James. Globalization and governance: ble- 
ak prospects for sustainability.

Bonn, Germany: Friedrich-Ebert-Stiftung, p. 11-29, 2003. Disponível em: < http://www.fes-globalization.org/ publications/030420_01_Bonn.pdf>. Acesso em: 25 fev 2016.

SALM, José Francisco; MENEGASSO, Maria Ester. O Curso de Administração Pública em tempos de coprodução do bem público e de governança pública: proposição e referências. In: Encontro de Administração Pública e Governança, 5, 2012, Salvador. Anais... Salvador: Associação Nacional de Pós-Graduação e Pesquisa em Administração, nov. 2012.

SANTOS, Marcos José Araújo dos; PINHEIRO, Leonardo Barboza; QUEIROZ, Igor de Assis Sanderson de. Governança na administração pública: concepções do modelo australiano de Edwards et al. (2012) vis-à-vis as contribuições teóricas. In: XXXVIII ENCONTRO DA ANPAD. Rio de Janeiro, 2014. Anais... Rio de Janeiro: Associação Nacional de Pós-Graduação e Pesquisa em Administração, 2014.
SCHEDLER, Andreas; DIAMOND, Larry Jay; PLATTNER, Marc. The self-restraining State: power and accountability in new democracies. London: Lynne Rienner Publishers, p.13-28, 1999.

SÍGOLO, Vanessa; MASCARENHAS, Thais. Participação popular, espaço público e autogestão. Caderno de Gestão Social, v.3, n.1, 2012, p.101-119.

SORENSEN, Eva. Conflict as driver of pluricentric coordination. Planning Theory, Denmark, v.13, n.2, 2014, p.152-169.

SORENSEN, Eva; TORFING, Jacob. Making governance networks democratic. Centre for Democratic Network Governance, Denmark: Roskilde University, 2004.

TRIBUNAL DE CONTAS DA UNIÃO (TCU). Governança pública: referencial básico de governança aplicável a órgãos e entidades da Administração Pública e ações indutoras de melhoria. Brasilia, 2014. Disponível em: <www.tcu.gov.br>. Acesso em: 15 mar. 2015. 


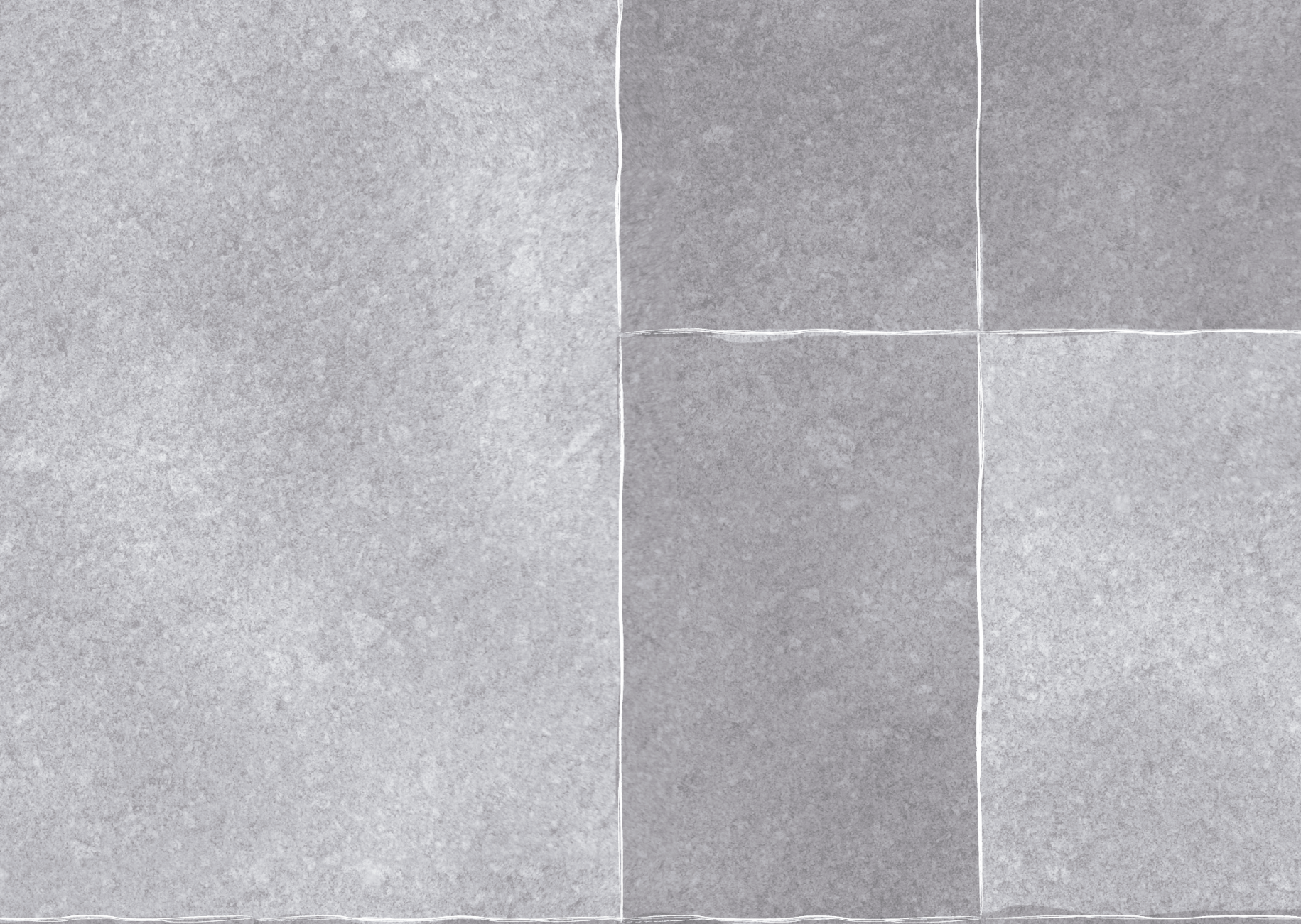

